Available online at http://journal.stkip-andi-matappa.ac.id/index.php/histogram/index

Histogram : Jurnal Pendidikan Matematika 2 (2), 2018, 169-182

\title{
PROFIL KEMAMPUAN SPASIAL DALAM MENYELESAIKAN MASALAH GEOMETRI SISWA YANG MEMILIKI KECERDASAN LOGIS
}

\author{
Herman Alimuddin ${ }^{1}$ Andi Trisnowali MS $^{2}$ \\ STKIP Andi Matappa ${ }^{1}$ \\ STKIP Muhammadiyah Bone ${ }^{2}$ \\ * Corresponding Author. Email: herman.alimuddin@yahoo.co.id \\ Received: 1 September 2018; Revised: 21 September 2018; Accepted: 27 September 2018
}

\section{ABSTRAK}

Penelitian ini bertujuan untuk mengetahui profil kemampuan spasial dalam menyelesaikan masalah geometri siswa yang memiliki kecerdasan logis matematis ditinjau dari perbedaan gender. Jenis penelitian deskriptif dengan pendekatan kualitatif. Peneliti bertindak sebagai instrumen utama yang dipandu oleh tes kecerdasan logis matematis, tes linguistik, TKSMG dan pedoman wawancara yang valid. Pengumpulan data dilakukan melalui pemberian tes kecerdasan logis matematis pada beberapa calon subjek untuk memperoleh subjek penelitian sebanyak 4 subjek terdiri dari 2 subjek laki-laki dan 2 subjek perempuan. Subjek penelitian adalah siswa kelas XI SMA Negeri 2 Pangkep. Hasil penelitian menunjukkan, dalam menyelesaikan masalah geometri: (1) terkait kerangka acuan, subjek laki-laki dominan menggunakan kemampuan spasialnya sedangkan subjek perempuan menggunakan kemampuan spasial dan penalaran logisnya secara bersama-sama (2) terkait konservasi jarak, subjek laki-laki dan subjek perempuan menggunakan kemampuan spasial dan penalaran analitiknya serta kemampuan menarik suatu kesimpulan, (3) terkait representasi spasial, subjek laki-laki dan subjek perempuan mengintegrasikan kemampuan spasial dan kecerdasan logis matematisnya, (4) terkait rotasi mental, subjek laki-laki dominan menggunakan kemampuan spasialnya sedangkan subjek perempuan kurang menggunakan kemampuan spasialnya, (5) terkait hubungan proyektif, subjek laki-laki dan perempuan mengintegrasikan kemampuan spasial dan penalaran logisnya, (6) kemampuan spasial subjek laki-laki dan subjek perempuan yang memiliki kecerdasan logis matematis tinggi berada pada level tinggi.

Kata kunci: Kemampuan Spasial, Kecerdasan Logis Matematis, Kecerdasan Linguistik

How to Cite: Alimuddin, H., Trisnowali, A. (2018). Profil kemampuan spasial dalam menyelesaikan masalah geometri siswa yang memiliki kecerdasan logis. Histogram: Jurnal Pendidikan Matematika, 2(2), 169-182. doi: http://dx.doi.org/10.31100/histogram.v2i2.238

\section{Permalink/DOI:}

http://dx.doi.org/10.31100/histogram.v2i2.238

\section{PENDAHULUAN}

Matematika menjadi salah satu mata pelajaran wajib di sekolah sebab matematika merupakan mata pelajaran mendunia yang sangat berperan penting terhadap kemajuan ilmu pengetahuan dan teknologi. Peranan matematika ini menjadi sangat diperhitungkan sebab 


\section{Histogram: Jurnal Pendidikan Matematika, 2 (2), 2018 - 170 Herman Alimuddin, Andi Trisnowali MS}

menjadi pelayan bagi disiplin ilmu lain serta dapat melatih kemampuan berpikir tingkat tinggi.

Salah satu materi dalam pembelajaran matematika yang posisinya tergolong penting adalah geometri. Saking pentingnya, materi geometri diberikan kepada siswa mulai dari tingkat sekolah dasar hingga di tingkat menengah atas. Namun pada kenyataannya, walaupun materi geometri telah dikenal siswa sejak di sekolah dasar, siswa SMA kerap kali mengalami kesulitan ketika dihadapkan dengan materi ini lagi khususnya pada pemecahan masalah geometri.

Geometri merupakan salah satu cabang ilmu matematika. Geometri merupakan kunci untuk memahami alam dengan segala bentuknya yang ada di dunia. Adapun menurut Kartono (Khotimah, 2013), berdasarkan sudut pandang psikologi, geometri merupakan penyajian abstraksi dari pengalaman visual dan spasial, misalnya bidang, pola, pengukuran dan pemetaan. Geometri tidak hanya mengembangkan kemampuan kognitif siswa tetapi juga membatu dalam pembentukan memori yaitu objek konkret menjadi abstrak. Berdasarkan pendapat tersebut maka geometri merupakan materi penting dalam pembelajaran matematika (Khotimah, 2013).

Galileo mengungkapkan betapa pentingnya geometri untuk memahami dunia kita. Dunia menurutnya ditulis dalam bahasa matematika berupa segitiga, lingkaran, dan bendabenda geometris lainnya. Galileo berpikir bahwa geometri merupakan alat penting untuk memahami alam semesta dan oleh sebab itu sangatlah penting untuk memahami dasardasarnya, memahami karakteristik bagian-bagian geometri, mempelajari hubungan di antaranya serta mampu mengklasifikasikannya (Kok \& Davasligil, 2014).

Menurut NCTM (dalam Ristontowi, 2013), salah satu standar diberikannya geometri di sekolah adalah agar anak dapat menggunakan visualisasi, mempunyai kemampuan penalaran spasial dan pemodelan geometri untuk menyelesaikan masalah.

Pada dasarnya geometri mempunyai peluang yang lebih besar untuk dipahami siswa dibandingkan dengan cabang matematika yang lain. Hal ini karena ide-ide geometri sudah dikenal oleh siswa sejak sebelum mereka masuk sekolah, misalnya garis, bidang dan ruang. Meskipun geometri diajarkan, namun kenyataan di lapangan menunjukkan bahwa materi geometri kurang dikuasai oleh sebagian besar siswa. Masih banyak siswa yang mengalami kesulitan dalam belajar geometri, salah satunya pada tingkatan SMA. 


\section{Histogram: Jurnal Pendidikan Matematika, 2 (2), 2018 - 171 Herman Alimuddin , Andi Trisnowali MS}

Menurut Kartono (Khotimah, 2013), berdasarkan sudut pandang psikologi, geometri merupakan penyajian abstraksi dari pengalaman visual dan spasial, misalnya bidang, pola, pengukuran dan pemetaan. Oleh karena itu jelas bahwa kemampuan spasial sangat berperan penting dalam pembelajaran tentang geometri ini.

Kemampuan spasial (pandang ruang) menurut Ristontowi (2013) yaitu (1) kemampuan untuk mempersepsi yakni menangkap dan memahami sesuatu melalui panca indra, (2) kemampuan mata khususnya warna dan ruang, (3) kemampuan untuk mentransformasikan yakni mengalihbentukkan hal yang ditangkap mata ke dalam bentuk wujud lain, misalnya mencermati, merekam, menginterpretasikan dalam pikiran lalu menuangkan rekaman dan interpretasi tersebut ke dalam bentuk lukisan, sketsa dan kolase. Semua kemampuan tersebut perlu dimiliki untuk mempelajari geometri. Demikian pentingnya kemampuan spasial ini perlu dimiliki oleh siswa sehingga guru dituntut untuk memperhatikan kemampuan ini dalam pembelajaran di kelas. Namun pada kenyataannya kemampuan spasial yang dimiliki siswa masih lemah. Hal ini terungkap melalui penelitian yang dilakukan oleh Kariadinata di tahun 2008 yang hasilnya menunjukkan bahwa masih banyak persoalan geometri yang memerlukan visualisasi untuk pemecahan masalah dan pada umumnya siswa merasa kesulitan mengkonstruksi bangun ruang geometri (Ristontowi, 2013).

Sedangkan menurut Piaget \& Inhelder (Yilmaz, 2009) kemampuan spasial merupakan konsep abstrak yang di dalamnya meliputi hubungan spasial (kemampuan untuk mengamati hubungan posisi objek dalam ruang), kerangka acuan (tanda yang dipakai sebagai patokan untuk menentukan posisi objek dalam ruang), hubungan proyektif (kemampuan untuk melihat objek dari berbagai sudut pandang), konservasi jarak (kemampuan untuk memperkirakan jarak antara dua titik), representasi spasial (kemampuan untuk merepresentasikan hubungan spasial dengan memanipulasi secara kognitif), rotasi mental (membayangkan perputaran objek dalam ruang).

Berdasarkan pengertian dari kemampuan spasial sendiri dapat diketahui bahwa kemampuan spasial ini sendiri membutuhkan kemampuan berpikir tingkat tinggi dalam mengamati dunia spasial serta membayangkan bentuk-bentuk geometri sebab membutuhkan daya imajinasi yang tinggi. Dalam kemampuan spasial juga diperlukan adanya pemahaman kiri-kanan, pemahaman perspektif, menghubungkan konsep spasial dengan angka, kemampuan dalam mentransformasi mental dari bayangan visual yang tak lain merupakan kerja otak. Tentunya dalam kemampuan-kemampuan ini, kecerdasan logis ISSN: 2549-6700 (print), ISSN 2549-6719 (online) 


\section{Histogram: Jurnal Pendidikan Matematika, 2 (2), 2018 - 172 Herman Alimuddin , Andi Trisnowali MS}

matematis siswa juga sangat berperan penting sehingga dapat dikatakan bahwa kecerdasan logis matematis yang merupakan salah satu dari teori kecerdasan ganda oleh Gardner ini erat kaitannya dengan kemampuan spasial itu sendiri. Secara teoritis, kecerdasan logis matematis sebagai salah satu dari kecerdasan majemuk (multiple intellegence) bisa didefinisikan sebagai kapasitas seseorang untuk berpikir secara logis dalam memecahkan kasus atau permasalahan dan melakukan perhitungan matematis. Orang dengan kecerdasan logis matematis mempunyai kemampuan mengelola logika dan angka dengan aktivitas utama berpikir logis, berhitung, menyusun pola hubungan serta memecahkan masalah. Hal ini terkait dengan penelitian yang dilakukan oleh I Gan Trisna Jayantika dkk tahun 2013 yang menunjukkan bahwa ada hubungan antara kecerdasan spasial dan kecerdasan logis matematis. Siswa yang memiliki kecerdasan logis matematis yang tinggi tentunya memiliki kecerdasan spasial yang tinggi pula. Hal ini menunjukkan bahwa semakin tinggi kecerdasan logis matematis maka semakin tinggi pula kemampuan spasial siswa dimana kemampuan spasial terkait dengan kecerdasan spasial itu sendiri.

Terkait dengan kemampuan spasial, tiap siswa memiliki kemampuan spasial yang berbeda-beda. Perbedaan yang paling sering diteliti ialah perbedaan berdasarkan gender. Menurut Ashari (2014), ada beberapa penelitian yang menyatakan bahwa terdapat perbedaan yang signifikan antara laki-laki dan perempuan dalam hal kemampuan penalaran spasialnya misalnya dalam penelitian yang dilakukan oleh Ganley \& Vasilyeva di tahun 2011. Namun, menurut Tiang dan Huang masih di tahun yang sama, tidak terdapat perbedaan antara laki-laki dan perempuan dalam hal kemampuan penalaran spasialnya. Penemuan ini kemudian menginspirasi penulis untuk meneliti lebih mendalam mengenai kemampuan spasial siswa yang memiliki kecerdasan logis matematis tinggi ditinjau dari perbedaan gendernya.

Berdasarkan latar belakang yang telah dikemukakan di atas, maka tujuan penelitian ini adalah untuk mengetahui: (1) Bagaimana profil kemampuan spasial dalam menyelesaikan masalah geometri siswa bergender laki-laki yang memiliki kecerdasan logis matematis tinggi? (2) Bagaimana profil kemampuan spasial dalam menyelesaikan masalah geometri siswa bergender perempuan yang memiliki kecerdasan logis matematis tinggi?

(3) Bagaimana perbandingan profil kemampuan spasial dalam menyelesaikan masalah geometri siswa bergender laki-laki dan siswa bergender perempuan yang memiliki kecerdasan logis matematis tinggi? 


\section{METODE PENELITIAN}

Penelitian ini merupakan penelitian kualitatif yang bertujuan menggambarkan profil kemampuan spasial dalam menyelesaikan masalah geometri siswa yang memiliki kecerdasan logis matematis ditinjau dari perbedaan gender. Instrumen dalam penelitian ini adalah peneliti sendiri sebagai instrumen utama yang dipandu tes kecerdasan logis matematis, tes kemampuan spasial dalam menyelesaikan masalah geomteri (TKSMG), pedoman wawancara dan rubrik penilaian kemampuan spasial yang telah divalidasi. Subjek penelitian adalah siswa kelas XI SMA Negeri 2 Pangkep yang terdiri dari 2 orang siswa laki-laki dan 2 orang siswa perempuan yang memiliki kecerdasan logis matematis tinggi.

Langkah- langkah dalam proses penelitian ini adalah:

1. Memberikan tes kecerdasan logis matematis pada 51 calon subjek untuk memperoleh minimal 2 siswa laki-laki dan 2 siswa perempuan yang memiliki kecerdasan logis matematis tinggi yang selanjutnya dijadikan sebagai subjek penelitian. Tes kecerdasan logis matematis diadaptasi dari tes kecerdasan logis matematis yang telah baku yang terdiri dari 21 soal pilihan ganda.

2. Menganalisis dan mengkonversi hasil tes menjadi tiga kategori yaitu kecerdasan logis matematis tinggi, sedang dan rendah dengan mengikuti pembagian $27 \%$ kelompok atas untuk kategori tinggi dan $27 \%$ kelompok bawah untuk kategori rendah dan persentase sisanya untuk kategori sedang.

3. Memilih 2 subjek laki-laki dan 2 subjek perempuan dari siswa yang memiliki kecerdasan logis matematis tinggi kategori tinggi dengan pertimbangan guru berdasarkan kemampuan subjek mengkomunikasikan jalan pikirannya.

4. Memberikan Tes Kemampuan Spasial dalam menyelesaikan Masalah Geometri (TKSMG) kepada 4 subjek terpilih. Tes berupa soal-soal geometri yang disusun berdasarkan indikator kemampuan spasial yaitu kerangka acuan, konservasi jarak, representasi spasial, rotasi mental, dan hubungan proyektif. Tes dikerjakan siswa pada lembar jawaban yang kemudian subjek diwawancarai berdasarkan pedoman wawancara seputar hasil pekerjaannya.

5. Melakukan reduksi, abstraksi, transformasi dan pengkategorian pada data serta melakukan triangulasi sumber untuk mendapatkan data yang valid.

6. Menafsirkan dan menyimpulkan hasil penelitian. ISSN: 2549-6700 (print), ISSN 2549-6719 (online) 


\section{HASIL PENELITIAN DAN PEMBAHASAN}

\section{A. Hasil Penelitian}

Berdasarkan hasil tes kemampuan spasial dalam menyelesaikan masalah geometri dan hasil wawancara pada subjek laki-laki, maka diperoleh hasil sebagai berikut:

1. Subjek bergender laki-laki menyelesaikan masalah geometri terkait kerangka acuan dengan dominan menggunakan kemampuan spasialnya yaitu dengan menggunakan suatu tanda dalam menentukan posisi objek-objek lain di dalam ruang. Subjek laki-laki secara keseluruhan membayangkan pembentukan kubus berdasarkan jaring-jaring kubus secara abstrak.

2. Dalam penentuan lintasan terpendek, subjek bergender laki-laki mula-mula menggunakan kemampuan spasialnya yaitu memperkirakan jarak antara antara dua titik dengan memperkirakan lintasan-lintasan mana yang terpendek. Setelah itu, subjek menggunakan kecerdasan logis matematisnya dengan membandingkan lintasan-lintasan terpendek tersebut. Selanjutnya, dengan kembali menggunakan kecerdasan logis matematisnya dalam hal penarikan kesimpulan, subjek bergender laki-laki menentukan lintasan mana yang paling pendek.

3. Penggunaan rumus phytagoras menunjukkan bahwa subjek bergender laki-laki menggunakan pengetahuan matematikanya dalam merepresentasikan hubungan spasial antara dua objek dalam ruang dengan memanipulasi secara kognitif. Hal ini menunjukkan bahwa subjek mengintegrasikan kemampuan spasial dan kecerdasan logis matematisnya dalam menyelesaikan masalah geometri terkait representasi spasial.

4. Dalam pengerjaan soal rotasi mental, subjek bergender laki-laki secara dominan menggunakan kemampuan spasialnya dalam hal membayangkan perputran objek dalam ruang.

5. Subjek bergender laki-laki mengintegrasikan kemampuan spasialnya dalam melihat objek dari berbagai sudut pandang dengan kecerdasan logis matematisnya dalam hal penalaran logis.

Berdasarkan hasil tes kemampuan spasial dalam menyelesaikan masalah geometri dan hasil wawancara pada subjek perempuan, maka diperoleh hasil sebagai berikut:

1. Subjek bergender perempuan menggunakan kemampuan spasialnya terlebih dahulu yaitu dengan menggunakan tanda sebagai patokan untuk menentukan posisi objek 


\section{Histogram: Jurnal Pendidikan Matematika, 2 (2), 2018 - 175 Herman Alimuddin , Andi Trisnowali MS}

dalam ruang. Setelah itu, subjek menggunakan penalaran logisnya dalam menentukan posisi objek-objek lain yaitu dengan memperhatikan hubungan antara objek tersebut.

2. Subjek bergender perempuan menggunakan kemampuan spasialnya dalam memperkirakan lintasan-lintasan terpendek antara dua titik dengan membandingkan lintasan-lintasan lainnya. Subjek kemudian menggunakan penalaran analitiknya dalam membandingkan lintasan-lintasan tersebut dan menarik kesimpulan dari hasil analisisnya.

3. Dalam menyelesaikan masalah geometri terkait representasi spasial, subjek bergenre perempuan mengintegrasikan kemampuan spasialnya dalam merepresentasikan hubungan spasial antara dua objek dalam ruang dengan kecerdasan logikanya dalam menggunakan pengetahuan matematikanya.

4. Subjek bergender perempuan lebih cenderung berpikir logis daripada membayangkan secara mental perputaran objek dalam ruang ketika menyelesaikan masalah geometri terkait rotasi mental.

5. Selain menggunakan kemampuan spasialnya dalam melihat objek dari berbagai sudut pandang, subjek bergender perempuan juga berpikir secara logis dalam menyelesaikan masalah geometri terkait hubungan proyektif.

Adapun perbandingan profil kemampuan spasial subjek laki-laki dan perempuan dari hasil penelitian adalah sebagai berikut:

1. Dalam menyelesaikan masalah geometri terkait kerangka acuan, subjek laki-laki dominan melakukan aktivitas membayangkan dalam menetukan posisi tiap sisi kubus dengan patokan gambar huruf A sedangkan subjek perempuan menggunakan gambar huruf A sebagai patokan terlebih dahulu lalu dilanjutkan membayangkan posisi sisi-sisi lain berdasarkan sisi yang telah terbentuk sebelumnya berdasarkan hubungan sisi-sisi tersebut.

2. Dalam menyelesaikan maslah geometri terkait konservasi jarak, subjek laki-laki dan subjek perempuan memperkirakan terlebih dahulu lintasan-lintasan mana saja yang mungkin merupakan lintasan terpendek kemudian membandingkan lintasan-lintasan tersebut. Subjek laki-laki dan perempuan selanjutnya menarik suatu kesimpulan dari hasil perbandingan.

3. Dalam menyelesaikan masalah geometri terkait representasi spasial, subjek laki-laki dan subjek perempuan merepresentasikan hubungan spasial antara semut dan permen 


\section{Histogram: Jurnal Pendidikan Matematika, 2 (2), 2018 - 176 Herman Alimuddin , Andi Trisnowali MS}

dengan memanipulasi secara kognitif sekaligus menggunakan pengetahuan matematikanya yaitu dengan menggunakan rumus phytagoras.

4. Dalam menyelesaikan masalah geometri terkait rotasi mental, subjek laki-laki menggunakan dominan kemampuan membayangkannya lalu menggambarkan hasil bayangannya sedangkan subjek perempuan menggambarkan terlebih dahulu rotasi pertama lalu kedua dan hasil rotasinya pun diperoleh dengan menggunakan penalaran logisnya.

5. Dalam menyelesaikan masalah geometri terkait hubungan proyektif, subjek laki-laki dan subjek perempuan membayangkan gambaran susunan kubus dari atas dengan memadukan gambar tampak atas dan tampak samping kiri. Gambaran susunan kubus tampak kanan dibayangkan dengan hanya memperhatikan gambar susunan kubus tampak kiri yang secara logika merupakan gambar kebalikannya.

\section{B. Pembahasan}

Secara umum, kemampuan subjek laki-laki dan perempuan dalam menyelesaikan tes kemampuan spasial ini sama-sama berada pada level tinggi berdasarkan rubrik penilaian kemampuan spasial. Jawaban yang diberikan subjek laki-laki dan perempuan hampir benar semua dan jawaban yang diberikan pun beberapa hampir sama. Hal ini mengindikasikan bahwa siswa yang memiliki kecerdasan logis matematis tinggi juga memiliki kemampuan spasial yang baik sejalan dengan penelitian yang dilakukan oleh Jayantika (2013:8) yang menunjukkan bahwa kecerdasan spasial berkontribusi cukup besar terhadap kecerdasan logis matematis. Perbedaan yang mendasarinya adalah cara mengerjakan soal dan penggunaan kemampuan kognitifnya yang akhirnya menampilkan profil kemampuan spasial dari masing-masing gender.

Perbedaan yang paling menonjol adalah pada kemampuan menggunakan tanda sebagai patokan untuk menentukan posisi objek lain (kerangka acuan) dan kemamuan membayangkan perputaran objek dalam ruang (rotasi mental). Pada masalah geometri terkait indikator kerangka acuan, subjek bergender laki-laki sepenuhnya membayangkan posisi objek lain dengan patokan suatu tanda sedangkan subjek bergender perempuan menentukan posisi objek lain dengan cenderung melihat hubungan antar objek.

Terkait masalah geometri dengan indikator rotasi mental, subjek bergender lakilaki menggunakan kemampuan membayangkannya dengan bingkai yang lebih abstrak terbukti dengan pengerjaan soal rotasi mental yang sepenuhnya dilakukan dengan Copyright (c) 2018, Histogram: Jurnal Pendidikan Matematika ISSN: 2549-6700 (print), ISSN 2549-6719 (online) 


\section{Histogram: Jurnal Pendidikan Matematika, 2 (2), 2018 - 177 Herman Alimuddin , Andi Trisnowali MS}

membayangkan tanpa membuat catatan-catatan bantuan terlebih dahulu seperti yang dilakukan oleh subjek bergender perempuan yang menggunakan kemampuan membayangkannya lebih konkrit. Catatan-catatan subjek bergender perempuan kemungkinan disebabkan karena ingin memastikan jawabannya terlebih dahulu. Hal ini terkait dengan teori yang dikemukakan oleh Linn dan Petersen (1985 dalam Yilmaz: 2009) bahwa perempuan lebih berhati-hati, mengecek berulang kali pekerjaannya, dan membutuhkan waktu yang lebih lama dalam menjawab soal. Selain itu, penemuan oleh Mann (1990) dan Silverman (1996) dalam Geary (2001: 176) yaitu tentang keunggulan laki-laki terkait rotasi mental pada siswa SMA di Jepang, Amerika Utara, Eropa, dan Afrika juga mendukung hasil penelitian ini.

Walaupun kurang menggunakan kemampuan spasialnya, subjek bergender perempuan tetap bisa menyelesaikan masalah geometri terkait indikator rotasi mental ini yaitu dengan melibatkan kecerdasan logis matematisnya untuk menyelesaikan masalah. Secara umum dapat dikatakan bahwa subjek laki-laki cenderung menggunakan kemampuan spasial (membayangkan) sedangkan subjek bergender perempuan cenderung menggunakan logikanya. Hal ini mendukung teori yang dikemukakan oleh Tasni, 2012 yang menyatakan bahwa berpikir pada pria lebih banyak memfungsikan belahan otak kanannya dibandingkan otak kiri dalam mengambil suatu keputusan dimana otak kanan identik dengan kreativitas, khayalan bentuk atau ruang, berpikir lateral, tidak terstruktur, dan cenderung tidak memikirkan hal-hal yang terlalu mendetail. Hal ini dapat meminimalisasi ekspresi emosi dan intuisi perasaan sehingga laki-laki dapat berpikir secara terstruktur dalam rangkaian yang rumit sehingga menempatkan pria sebagai pribadi yang berani mengambil keputusan dan tidak terlalu memusingkan hal-hal yang sekunder seperti yang tampak pada penelitian ini yaitu subjek bergender laki-laki berani untuk langsung menjawab tes yang dihasilkan dari hasil membayangkan saja. Berpikir pada wanita cenderung menggunakan belahan otak secara bersamaan dimana otak kiri biasa diidentikkan dengan rapi, angka, urutan, tulisan, hitungan, logika, terstruktur, analitis, matematis, sistematis, linear, tahap demi tahap sehingga wanita berpikir secara menyeluruh dan penuh keraguan. Pada umumnya cara kerja belahan otak kanan dan kiri pada wanita dipengaruhi oleh nuansa emosi yang tinggi sehingga keputusan yang diambil memiliki warna emosionil. Pernyataan di atas sejalan dengan hasil penelitian ini yang menunjukkan bahwa subjek perempuan mengerjakan TKSMG dengan keraguan dibuktikan dengan 


\section{Histogram: Jurnal Pendidikan Matematika, 2 (2), 2018 - 178 Herman Alimuddin , Andi Trisnowali MS}

banyaknya catatan-catatan bantuan yang dibuat oleh subjek bergender perempuan dibandingkan subjek bergender laki-laki.

Terkait dengan masalah geometri yang disusun berdasarkan indikator konservasi jarak, subjek laki-laki dan perempuan sama-sama dominan menggunakan kecerdasan logis matematisnya khususnya kemampuan membandingkan dan mengambil suatu kesimpulan sedangkan terkait dengan masalah geometri yang disusun berdasarkan indikator representasi spasial dan hubungan proyektif, subjek bergender laki-laki dan subjek bergender perempuan cenderung mengintegrasikan kemampuan spasial dan kecerdasan logis matematisnya. Hal ini mengindikasikan bahwa pada pengerjaan masalah geometri yang disusun berdasarkan indikator kemampuan spasial, tidak menutup kemungkinan siswa membutuhkan kecerdasan logis matematisnya sebab keduanya merupakan kemampuan kognitif yang membutuhkan penalaran (National Academy of Science, 2006 dalam Ashari, 2014).

Berdasarkan pembahasan di atas, tampak perbedaan dan persamaan dalam menyelesaikan masalah geometri terkait dengan kemampuan spasial antara laki-laki dan perempuan dimana dapat disimpulkan bahwa subjek laki-laki lebih dominan menggunakan kemampuan spasialnya dibandingkan subjek bergender perempuan. Perbedaan kemampuan spasial antara laki-laki dan perempuan sudah sejak lama dibahas dan diteliti hingga sekarang. Banyak penelitian yang menyimpulkan bahwa kemampuan spasial laki-laki lebih baik (khususnya pada rotasi mental) daripada perempuan walaupun ada juga penelitian yang menyimpulkan sebaliknya dan ada yang menyimpulkan bahwa tidak ada perbedaan antara keduanya. Walaupun dalam penelitian ini peneliti tidak bisa menyimpulkan bahwa kemampuan spasial laki-laki lebih baik daripada kemampuan spasial perempuan, tapi tampak jelas bahwa ada perbedaan di antara keduanya yaitu dalam hal penggunaanya.

Laki-laki lebih dominan menggunakan kemampuan spasialnya kemungkinan disebabkan oleh beberapa hal. Penyebab adanya perbedaan kemampuan spasial antara laki-laki dan perempuan ini telah banyak dibahas di dalam berbagai literatur. Ada banyak literatur yang menjelaskan penyebab perbedaan kemampuan spasial antara laki-laki dan perempuan khususnya terkait dengan rotasi mental yang kemudian bisa digolongkan menjadi dua kategori besar yaitu : (1) faktor biologis dan (2) faktor sosial budaya (Yilmaz, 2009:91 dan Geary, 2001:176). 


\section{Histogram: Jurnal Pendidikan Matematika, 2 (2), 2018 - 179 Herman Alimuddin , Andi Trisnowali MS}

Dari segi biologis, para peneliti berfokus pada hormon dan perkembangan otak. Perempuan yang memiliki tingkat hormon androgen yang tinggi selama masa remajanya memiliki kemampuan spasial yang lebih baik dibandingkan perempuan lainnya (Hampson, Rovelt dan Altman, 1998 dalam Yilmaz, 2009:91). Sedangkan laki-laki di usia remaja yang memiliki tingkat hormon androgen yang lebih rendah memiliki kemampuan spasial yang lebih rendah dibandingkan laki-laki lainnya (Hier dan Crowley, 1982 dalam Yilmaz, 2009: 91).

Terkait dengan otak, manusia memiliki dua belahan otak yaitu belahan otak kanan dan belahan otak kiri. Belahan otak kanan berhubungan dengan kemampuan visual spasial sedangkan belahan otak kiri berhubungan dengan kemampuan bahasa dan verbal. Otak kanan pada laki-laki lebih berkembang dan lebih besar dibandingkan perempuan. inilah yang menyebabkan laki-laki lebih dominan menggunakan kemampuan spasialnya dibandingkan perempuan (de Lacoste, Hovarth, dan Woodward, 1991). Sebagai tambahan, Pakkenberg dan Gundrsen (1997) menyimpulkan bahwa laki-laki memiliki neuron neocortical $16 \%$ lebih banyak daripda perempuan dimana neuron ini memiliki kontribusi terhadap perbedaan kognitif (Yilmaz, 2009:91).

Lingkungan sosial budaya anak berpengaruh terhadap kemampuan spasialnya. Hal ini sejalan dengan pendapat Piaget dan Inhelder (Yilmaz, 2009) bahwa kemampuan spasial yang merupakan aspek dari kognisi berkembang sejalan dengan perkembangan kognitif anak. Dari segi lingkungan sosial budaya, peneliti menyimpulkan bahwa laki-laki memiliki lebih banyak kesempatan untuk mengembangkan kemampuan spasialnya dibandingkan perempuan. Permainan sejak kecil, kegiatan sehari-hari, olahraga, harapan orang tua dan lingkungan sekelilingnya bahkan sampai pekerjaan laki-laki sangat berpengaruh terhadap perkembangan kemampun spasialnya. Kebanyakan laki-laki ketika masih kecil bermain dengan kendaraan dan balok yang melibatkan manipulasi spasial sedangkan perempuan bermain dengan mainan hewan dan boneka yang membantu perkembangan kemampuan sosialnya. Olahraga laki-laki seperti sepak bola, basket, dan hoki es juga membutuhkan kemampuan spasial yang lebih besar dibandingkan olahraga yang biasa dilakukan perempuan seperti berenang dan lari. Dari segi pekerjaan, beberapa pekerjaan yang menuntut kemampuan spasial tinggi ternyata lebih banyak dipilih oleh laki-laki seperti pilot, insinyur dan ahli bedah (Yilmaz, 2009:92). Hal ini juga didukung oleh pendapat yang dikemukakan oleh Tzuriel dan Egozi (dalam Ashari, 2014) bahwa 


\section{Histogram: Jurnal Pendidikan Matematika, 2 (2), 2018 - 180 Herman Alimuddin , Andi Trisnowali MS}

kemampuan spasial berperan penting dalam interaksi sehari-hari dengan lingkungan seperti navigasi, mengenali dan memanipulasi objek, tugas akademik, dan mencari tempat.

Perempuan yang berpartisipasi dalam kegiatan musik, seni, atau atletik memiliki pengalaman dengan aktivitas spasial yang lebih banyak dan mendapat nilai yang lebih tinggi pada tes rotsi mental dibandingkan perempuan yang tidak mengikuti kegiatan tersebut. Hal ini menunjukkan bahwa latihan merupakan faktor yang penting yang menyebabkan adanya perbedaan gender pada kemampuan spasial (Ginn dan Pickens, 2005). Lohman (1986) menyebutkan bahwa perbedaan gender dalam kemampuan spasial ini bisa dieliminasi dengan latihan (McNulty, 2007:17-18).

Dengan banyaknya klaim tentang keunggulan laki-laki pada kemampuan spasial, beberapa peneliti menyimpulkan alasan yang mungkin menjadi penyebab perbedaan ini. Brownlow (2003) menyimpulkan bahwa rendahnya hasil yang ditunjukkan perempuan pada tes kemampuan spasial mungkin disebabkan oleh pemikiran negatif mereka terhadap pengetahuan yang selama ini mereka pahami bahwa laki-laki lebih baik dalam kemampuan spasial. Perempuan yang diberitahukan bahwa mereka akan diberi tes yang akan mengukur kemampuan spasial mereka akan memberikan hasil yang lebih rendah dibandingkan perempuan yang tidak diberitahukan terlebih dahulu (Crawford, 1995 dalam McNulty, 2007:16).

\section{KESIMPULAN DAN SARAN}

\section{A. Kesimpulan}

Berdasarkan pembahasan hasil penelitian di atas disimpulkan bahwa dalam menyelesaikan masalah geometri terkait kerangka acuan, subjek laki-laki dominan menggunakan kemampuan spasialnya sedangkan subjek perempuan menggunakan kemampuan spasial dan penalaran logisnya secara bersama-sama. Dalam menyelesaikan masalah geometri terkait konservasi jarak, subjek laki-laki dan subjek perempuan kurang menggunakan kemampuan spasialnya dan dominan menggunakan kecerdasan logis matematisnya.

Dalam menyelesaikan masalah geometri terkait representasi spasial dan hubungan proyektif, subjek laki-laki dan subjek perempuan mengintegrasikan kemampuan spasial dan kecerdasan logis matematisnya. 
Histogram: Jurnal Pendidikan Matematika, 2 (2), 2018 - 181

Herman Alimuddin , Andi Trisnowali MS

Dalam menyelesaikan masalah geometri terkait rotasi mental, subjek laki-laki dominan menggunakan kemampuan spasialnya sedangkan subjek perempuan kurang menggunakan kemampuan spasialnya.

Secara umum, kemampuan spasial subjek laki-laki dan subjek perempuan yang memiliki kecerdasan logis matematis tinggi berada pada level tinggi yang mengindikasikan bahwa kecerdasan logis matematis memiliki kontribusi terhadap kemampuan spasial.

\section{B. Saran}

Hasil penelitian ini diharapkan dapat menjadi rekomendasi bagi para guru bahwa keberhasilan siswa dalam belajar matematika khususnya materi geometri yang menggunakan kemampuan spasial juga dipengaruhi oleh kecerdasan logis matematis siswa. Selain itu, hasil penelitian ini juga menjadi rekomendasi guru agar lebih memahami karakter antara laki-laki dan perempuan dan penyebab perbedaannya di dalam mempelajari materi geometri terkait dengan kemampuan spasial sehingga guru dapat memikirkan metode ajar yang lebih efisien. 


\section{DAFTAR PUSTAKA}

Ashari, M. (2014). Profil Kemampuan Penalaran Spasial Peserta Didik Man Pinrang Berdasarkan Perbedaan Gender. Tesis. Tidak diterbitkan. Makassar : Program Pascasarjana UNM.

Geary, D, C., Soto, D., Catherine, M. (2001). Sex Differences in Spatial Abilities Among Adults from the United States and China. Evolution and Cognition. (Online) Vol. 7, No. 2 (web.missouri.edu/ gearyd/Geary\%26DeSoto.pdf), diakses 15 Januari 2015.

Jayantika, I, G, A, N, T., Ardana, I, M., \& Sudiarta, I, G, P. (2013). Kontribusi Bakat Numerik, Kecerdasan Spasial, dan Kecerdasan Logis Matematis terhadap Prestasi Belajar Matematika Siswa SD Negeri di Kabupaten Buleleng. e-Journal Program Pascasarjana Universitas Pendidikan Ganesha, (Online), Vol. 2 (http://pasca.undiksha.ac.id/e-journal/index.php/JPM/article/download/981/732), diakses 17 Agustus 2014.

Khotimah, H. (2013). Meningkatkan Hasil Belajar Geometri Dengan Teori Van Hiele. Makalah disajikan dalam Seminar Nasional Matematika dan Pendidikan Matematika dengan tema "Penguatan Peran Matematika dan Pendidikan Matematika untuk Indonesia yang Lebih Baik”, UNY, Yogyakarta 9 November.

Kok, B., \& Davasligil, U. (2014). The Effect of Teaching Geometry Which is Differentiated based on the Parallel Curriculum for Gifted/Talented Student on Spatial ability. Journal for the Education of the Young Scientist and Giftedness. (Online), Vol. $\quad 2, \quad$ Issue 40-52 (http://jeysg.org/admin/b_bilgi_dosya/dosya/28062014025550_2014-2-1-5.pdf), diakses 15 Januari 2015.

McNulty, K, P. (2007). Gender Differences in Spatial Abilities: A Meta-Analysis. Senior Thesis : Psychology of Georgia Institute of Technology. Scholarly Materials and Research at Tech. (Online) (https://smartech.gatech.edu/bitstream/handle/1853/19945/KMcNulty.pdf?sequen $\mathrm{ce}=1$ ), diakses 15 januari 2015.

Ristontowi. (2013). Kemampuan Spasial Siswa melalui Pendekatan Pendidikan Matematika Realistik Indonesia dengan Media Geogebra. Makalah disajikan dalam Seminar Nasional Matematika dan Pendidikan Matematika dengan tema "Penguatan Peran Matematika dan Pendidikan Matematika untuk Indonesia yang Lebih Baik”, UNY, Yogyakarta 9 November.

Tasni, N. (2012). Eksplorasi pemecahan masalah ditinjau dari tingkat kompleksitas masalah dan perbedaan gender pada siswa kelas VIII A Smp negeri 4 bulukumba. Tesis. Tidak diterbitkan. Makassar : Pascasarjana Universitas negeri Makassar

Yilmaz, H, B. (2009). On the Development and Measurement of Spatial Ability. International Journal Electric of Elementary Education. (Online) Vol. 1, Issue 2 (http://www.iejee.com/1_2_2009/yilmaz.pdf), diakses 15 Januari 2015 